\title{
Emotional Advertisement the Altering Realm of Integrated Marketing Communication
}

\author{
Mrs. Athira Keerthi R, Mr. Pradeep S Mr.Prabhakar K, \\ Principal, Royal Institutions, Bangalore. \\ Assistant professor, MBA, SVIT, Bangalore \\ Assistant professor, MBA, RRIAS,Bangalore
}

\begin{abstract}
Operating a business without advertisement is just like "winking at a beautiful girl in the dark" where we know what we are doing but she doesn't know anything. The actual enormous advertisement of all time has captured the emotional instant, has wrapped their brands in the words and images of that emotional moment and their served that package up for sale to those alike emotions. The cost efficiency becomes the driven force of increasing wealth in the Indian context through integrated marketing communication. The diversified cultural practices of Indians are creating opportunities for the corporate to take on emotional advertisement to communicate. The primary objective of the research is to understand the concept of integrated marketing communication, emotional advertisement and its impact on purchaser behavior.
\end{abstract}

Key words: Advertisement, Cost efficiency, Diversified cultural practice, Emotional, Purchaser behavior.

\section{Introduction}

Emotions are becoming the exclusive character of Indians. Based on this concept only, advertising firms are using emotions in advertisement as tool to be a magnet for the audience. All are being weapons of advertising firms to kill viewers to buy any other product than a product for which an advertisement is made.

Laughing, crying, and enjoying sad, upset hearing, speaking, showing....... Is because of feeling emotions sentiments and affection. Emotions will transfer information very quicker than other. Most of the advertising firms are trying to get the notice of the viewer by the way of emotions.

Does the emotional advertisement give impact on Indians?

This question arrives because Indians are bound with the emotions in their daily schedule.

\section{Advertisement}

Every piece of advertising turns the attention of the readers or listeners or the viewers towards the product or a service. Anything that turns the attention to an article or a service or an idea might be called as advertising. Advertising is an integral part of our social and economic system .Advertising the product or a service or an idea has been doing wonders in the sphere of distribution. Because, it is quite proficient for influencing the course of consumption, affecting the process of production, extending the exchange and diversifies the distribution.

\section{Emotional intelligence}

Emotional intelligence is the ability to identify, assess and control the emotions of oneself, of others and of groups. Emotional intelligence as ,"the subset of social intelligence that involves the ability to monitor one's own and other's feeling and emotions, to differentiate among them to use this information to guide one's thinking and action's. Emotional intelligence has four factors; they are perception of the emotion, the ability to understand emotion, the ability reason using emotions and the ability to manage emotions.

\section{Buying behavior}

Behavior is a mirror in which every one shows his or her image .Buying behavior is the process where by individuals choose whether, what, when, where, how, and from whom to purchase goods and services . Buying behavior is all the psychological, social and physical behavior of probable customers as they become aware of evaluate, purchase, consume and tell others about the products and services.

\section{Need Of The Paper}

All the firms are tiresome to promote the products and service through advertisement. The main intention of advertisement is to switch the prospective customer in to sales. By the way of advertisement, needs to convert the prospective customer into sales. By the way of advertisement, the firms are expecting more sales, but really advertisements gives awareness to the customer about the various products and services which are available in the market.Basically, the Indian customers are highly sensitive towards choosing the products and 
services. The customers are having various parameters to select the products and services. Is emotional advertisement, a parameter for Indians in their buying behavior? Thus the research work is done to know the realm and role of emotional intelligence.

\section{STATEMENT OF THE PROBLEM}

Now a day's most of the advertising firms are focusing the viewer to see their advertisement by creating emotional relationship with them the firms are believed by showing the advertisements emotionally, they can create emotional bond to their products and services with the customer. Thus the study is to know about the role of emotional advertisement.

\section{OBJECTIVES OF THE STUDY}

1. To know whether there is emotional attachment with the buying behavior.

2. To know whether Indians are influenced towards emotional advertisements.

3. To know the level of awareness about the emotional advertisement.

4. To know who is more emotionally attracted and the impact of emotional advertisement.

\section{RESEARCH METHODOLGY}

The data collected for the research are

- Primary data

- Secondary data

For the purpose of research both primary and secondary data are used. Primary data is collected through the questionnaire and discussion. Secondary data is collected through the internet.

\section{Limitation}

*Due to time constraint, very small sample size is taken.

*Analization defect may reflect the analysis and there by the research paper result.

\section{Analysis}

The sample size has taken 100 respondents, but received only 88 respondents. The analysis has done on the se respondents only. Out of which 46 respondents are female and 42 respondents are male. The analysis has covered all age groups literates and illiterates too.

\begin{tabular}{|c|c|c|c|c|c|}
\hline S.No & Particulars & $\begin{array}{l}\text { Male } \\
\text { Yes }\end{array}$ & $\begin{array}{l}\text { Male } \\
\text { No }\end{array}$ & $\begin{array}{l}\text { Female } \\
\text { Yes }\end{array}$ & $\begin{array}{l}\text { Female } \\
\text { No }\end{array}$ \\
\hline 1 & Are you aware of emotional advertisement & $100 \%$ & $0 \%$ & $100 \%$ & $0 \%$ \\
\hline 2 & Do you like emotional advertisement & $55 \%$ & $45 \%$ & $88 \%$ & $12 \%$ \\
\hline 3 & Are you attracted by emotional advertisement & $30 \%$ & $70 \%$ & $90 \%$ & $10 \%$ \\
\hline 4 & Do you understand the message what they convey in emotional advertisement & $50 \%$ & $50 \%$ & $38 \%$ & $62 \%$ \\
\hline 5 & Are emotional advertisement sensible to the products & $65 \%$ & $35 \%$ & $56 \%$ & $44 \%$ \\
\hline 6 & Did you feel emotions are necessarily to be used in advertisement & $28 \%$ & $72 \%$ & $46 \%$ & $54 \%$ \\
\hline 7 & Do emotional advertisement hold you for the longer period & $8 \%$ & $92 \%$ & $15 \%$ & $85 \%$ \\
\hline 8 & Are you emotionally bound with any advertisement & $88 \%$ & $12 \%$ & $78 \%$ & $22 \%$ \\
\hline 9 & Have you discussed about emotional advertisement with any other & $26 \%$ & $74 \%$ & $36 \%$ & $64 \%$ \\
\hline 10 & $\begin{array}{l}\text { Did you fell that companies are trying to hide the feature of product with the help } \\
\text { of emotions in advertisements }\end{array}$ & $82 \%$ & $18 \%$ & $91 \%$ & $9 \%$ \\
\hline 11 & Did emotional advertisement influence you to purchase the products & $77 \%$ & $23 \%$ & $74 \%$ & $26 \%$ \\
\hline 12 & If yes have you purchase & $70 \%$ & $30 \%$ & $69 \%$ & $31 \%$ \\
\hline 13 & $\begin{array}{l}\text { After purchase, have you ever come across any product which you have been } \\
\text { cheated by seeing such emotional advertisements }\end{array}$ & $23 \%$ & $77 \%$ & $13 \%$ & $87 \%$ \\
\hline
\end{tabular}

\section{Interpretation}

From the above table, both male and female respondent are aware about the emotional advertisement. Though they are aware of such advertisement, female like and attracted by such advertisement, when compare to the male. Message which is conveyed in the emotional advertisement are understandable by male then female. From this, though the female respondents are attracted towards the emotional advertisement without understanding the message which carries in the advertisement. Both male and female respondents are felt, emotions are not necessarily to be used much in advertisements. Especially some of the emotional advertisements are sensible towards the products but female respondents are felt which is not sensible towards the products. This may be reflection of female respondents are not understand the message which is conveyed in the emotional advertisements. Emotional advertisements are not remembered by the respondents for the longer period. Than the female respondents, male respondents are more bounded to the emotional advertisement. This 
analysis is contradictions to the male respondents are not attracted towards emotional advertisement then female. The respondents are not discussing much about emotional advertisement with others. Female respondents are felt emotional advertisements are used to hide the features of the products than male respondents. Though both the respondents are having different opinion about the emotional advertisements but these advertisements are influence the respondents to purchase the products. Not only the emotional advertisement influenced, the most of the respondents are purchase the products and services. After purchase the products, few respondents are felt they have cheated by the way emotional advertisement.

By the open-ended questions, male respondents like friendly and funny related emotional advertisements, whereas female respondents like health and family related emotional advertisement. Among recent emotional advertisements the female respondents have more liking towards jewelry and cosmetics advertisements, whereas male respondents have more liking towards insurance and telecommunication industry advertisement.

\section{Conclusion}

Now a days selling the product in the competitive market is not easy. But day by day so many products are increased in this modern world. Without the promotional strategy, selling the new or existing products will become impossible. The advertisements are one of the familiar promotional aid for selling the products or services. Various types of advertisement methodologies are aims towards attracting the prospective customers. Most of the advertising firms are using emotional type of advertisement; this is because in general Indians are emotionally attracted towards products and service. The research work has proved that respondents are attracted by emotional advertisements. Emotional advertisement are not only attracted the respondent it has provoked the respondents for purchasing the product and services. Especially family and health related emotional advertisements are influenced more respondents to purchase the products or service. But few respondents are felt those advertisement are hided the feature and they had been cheated by projecting the false statement which shown in the advertisements. Though emotional advertisements are attracted the respondents but they not remember such advertisements for the longer period. For repeat purchase, emotional advertisements are bringing the alternatives products in the process of buying behavior. At a same time, Indian are not hundred percent emotional towards their buying behavior. the respondents are not emotionally bounded with technical related products. Thus the research concluding that, emotional advertisements are not suitable for all type of products. In the life cycle of the Indians, emotional advertisements play a vital role and it's giving impact on their buying behavior.

[1] http://en.wikipedia.org/wiki/emotional_intelligence

\section{References}

[2] http://psychology.about.com/od/personalitydevelopment/a/emotionalintell.htm

[3] http://indian-amps.blogspot.com/2011/01/indians-emotional-valcano-burst.html

[4] http://in.answers.yahoo.com/question/index?qid=20100312041251AAcoMMU

[5] http://managementparadise.com, 